\title{
Reciprocity, Enforcement, and Economic Remittances
}

Samoie villagers in need have found the village's Facebook page an effective means of mobilizing resources through the diaspora network. In late May 2019, several images of a badly burned child from Nahr al-Bared popped up on the page, accompanied by a short narrative of the tragedy. The young boy had been playing near his father's workshop when an accident occurred, and he was burned over 80 percent of his body. He was expected to survive with proper medical attention, including skin grafts and physical rehabilitation. However, UNRWA medical aid would not cover all the costs of the procedures, and private hospitals in nearby Tripoli, Lebanon, require payment in advance. The costs of treatment were estimated at roughly US $\$ 20,000$. To bridge this gap in services in the refugee camp, the Samoie village Facebook users appealed to the diaspora network.

In April 2019, a young woman in her final year of medical school posted a plea on the Samoie village Facebook page for help paying her tuition fees. The demand for UNRWA postgraduate scholarships outstripped the supply.

Earlier, in May 2018, a well-respected sheikh passed away from a stroke on his return home from the hajj, or pilgrimage to Mecca. The community realized there was no communal facility in which to wash and enshroud his body, or anybody else's, in a dignified way. Again a transnational diaspora campaign began, to raise funds for a burial washroom via digital media platforms like the Samoie village Facebook page and the WhatsApp messaging service. In all three of these cases, the Samoie village community generated the resources to meet the community's needs.

Financial remittances are sent to the camps in three different ways. Most commonly, donors send cash with friends and family traveling to the region. One Samoie diaspora member said, "The main way most of us send money to the camps is through the shaanta, or suitcase method. There is always someone who 
is the brother or cousin or second uncle of a friend traveling to Lebanon. I give him the cash, and he manages to get it to my family network in the camps" (I-124L). This strategy mirrors the hawala, or informal money-lending system used in parts of Africa and South Asia. Many diaspora villagers also wire small emergency payments through Western Union. Though it is accessible, Western Union has costly fees and may raise red flags when people regularly send money to countries like Lebanon and Syria, as officials in the United States may view the transfers as potential security or terrorist threats. Finally, some members of the diaspora hold bank accounts in the camp host countries and use their accounts as a sort of village ATM to fund services and goods. One trusted family member can withdraw money from the bank account and distribute funds to those in need.

In the cases mentioned above, diaspora members coordinated efforts to send funds to the camp. For example, US $\$ 20,000$ was sent in digital payments to fund skin grafts for the burned child. The community found $\$ 6,000$ to pay for the young woman's last year of medical school. Contributions of more than $\$ 25,000$ covered the cost of the communal washroom (yet to be constructed), and the campaign even prompted a cemetery cleanup initiative by a camp religious organization. Contrary to the views of technology pessimists, digital spaces facilitated remittance flows from the Palestinian refugee diaspora, even among second- and third-generation community members who had never lived inside the camps or in Palestine.

In this chapter, I trace how one Palestinian Facebook page uses images, videos, narratives, and memories that reproduce a malleable form of Palestinian 'adat wa taqlid to encourage connection, mobilize the diaspora's resources, and fund needed goods and services. Building on Carol Stack's All Our Kin (1974), I show that patterns of gift exchange among people in poverty are embedded in well-defined kinship obligations and sanctions. Stack's ethnographic study of a poor Black community during the 1970s, in a space she refers to as the Flats, provides a useful comparative case for understanding poverty, reciprocity, and gift exchange among kin and kin-like groups. She illustrates the way the community invites reciprocity and enforces sanctions on shirkers. Likewise, I show how 'ayb, or shame, was used as a strategic tool for punishing shirkers and encouraging the members of the diaspora to give money and share resources with community members in need.

Though shame may seem like a weak tool compared to the formal mechanisms that a state might wield for enforcement of behavior, like a police force or established judicial system, in truth, shame is an effective informal tool for managing social interactions and encouraging reciprocal behavior. It is especially powerful among communities living separately from state structures (Kraybill 1998; Kraybill and Bowman 2002; Stack 1974). Drawing on an extensive literature, I compare Palestinian communities to Amish communities in Lancaster County, Pennsylvania that use shame and shunning, or Meidung, to enforce communal norms of obedience, loyalty, and selflessness and fund communal needs. 
While Stack's study predates ICTs, and the Amish people explicitly reject the use of digital technology in most circumstances, Palestinians who are forcibly separated by geographic distance have found a way to use digital spaces to enforce shared norms and incentivize remittance flows. By patterning digital spaces on family and village structures, they generate a "high-context" digital culture in which certain norms are considered self-evident. Moreover, the continuous broadcasting of replicable narratives and images reminds people of communal expectations. To inspire remittance flows among the transnational diaspora, the Facebook page users and village elders in the real world wield ' $a y b$ to get people to do the "right" thing.

\section{COMMUNITY NEEDS IN PALESTINIAN \\ REFUGEE CAMPS}

Before exploring how remittances are cultivated in digital spaces among Palestinian refugees, it is helpful to identify the increasing difficulties Palestinians face in accessing basic goods and services in Nahr al-Bared and other Palestinian refugee camps across Lebanon. A joint American University of Beirut-UNRWA survey report conducted in 2010 and 2015 found that 65 percent of Palestinian refugee households in Lebanon live at or below the level of poverty. The survey included 2,974 Palestinian refugee households in the country's twelve Palestinian refugee camps and areas adjacent to the camps. In northern Lebanon, where Nahr al-Bared is located, poverty rates increased by 11 percent between 2010 and 2015 (Chaaban et al. 2016).

The residents' condition is desperate because of their social, economic, and political exclusion from Lebanese society. Though Palestinians refugees have lived in Lebanon for more than seventy years, they are still considered foreigners under Lebanese law. This status deprives them of basic rights enjoyed by the Lebanese, such as the right to own property in Lebanon. They face restrictive employment measures, such as being banned from some liberal and syndicate professions (Chaaban et al 2016; Hajj 2016). Despite the August 2010 amendments to Article 59 of the Labour Law and Article 9 of the Social Security Law, which waived workpermit fees for Palestine refugees born in Lebanon, the majority of Palestinians in Lebanon are still underemployed, in illegal work arrangements, or unemployed. In fact, fewer than 3.3 percent of Palestinians have an official employment contract, witnessed by a public notary, that enables them to apply for a work permit (Chaaban et al. 2016).

UNRWA serves as the official primary provider of health, education, and welfare services in Palestinian refugee camps. But the increasing demands on UNRWA, resulting from the ongoing conflicts and community needs in Gaza and Syria, and the complete defunding of UNRWA by the Trump administration in 2018, have created a severe gap in services. The AUB-UNRWA study concludes, 
"Decaying infrastructure, a dearth of recreational spaces, insufficient access to roads, deteriorated water and sewage treatment systems, contaminated water, and jerry-rigged electrical wires along with open drainage ditches paint a gloomy picture of the camps" (Chaaban et al. 2016, 7). Indeed, the gloom is pervasive, and the gap between the needs of the community and provision of public goods and services by UNRWA and host states has widened since the report was published. In the presence of this humanitarian catastrophe, diaspora remittances provide essential resources and services.

\section{DIASPORA ECONOMIC REMITTANCES AND ICTS}

Extensive surveys and open-ended interviews reveal the power of ICTs in harnessing diaspora resources to support the welfare of refugees living in the camps. With the proliferation of ICTs anchored in ahl and hamula structures and traditional behavioral norms, Palestinians in the diaspora have been able to enter into the digital process of community building, reciprocity, and generating economic remittances.

One of the central failures of services in Palestinian refugee camps is the lack of accessible and affordable burial. The cost of washing and enshrouding bodies, two of the main components of the Muslim jana'iz (burial rites), are prohibitively expensive for many people in Nahr al-Bared, especially since host states, aid agencies, and nationalist parties provide no financial support for funerary rites. The jana'iz are a rather simple set of guidelines for burial (see Halevi 2007). The body is wrapped in a shroud, normally of plain white linen. Sometimes a green Islamic banner is draped over the coffin, but simple shrouds are usually preferred, both to defray costs and to emphasize the egalitarian nature of Islam. Many refugees can barely afford the shroud, the burial process, and the tradition of feeding mourners. These are essential components of a dignified burial, and the inability to provide them creates distress and embarrassment at a time when the family is already grieving. To explore how the Samoie community has attempted to solve these difficulties, I interviewed members of the diaspora who had commented on obituary posts on the community Facebook page. My interviews and data analysis suggest that Palestinians overcame the burial-cost dilemma by using the authority of pre-1948 village religious elders to activate patriarchal networks online.

After Nahr al-Bared was destroyed in 2007, the main cemetery and community burial washroom were rendered unusable. Though UNRWA rebuilt the homes of refugees, the community had to construct its own washroom and find additional cemetery space. In the short term, Sheikh Jihad, the revered religious elder in the camp, remedied the problem by asking well-to-do male family members from the same village as a deceased person in the camp to donate sums of money ranging from US $\$ 20$ to $\$ 50$ to pay for the washing of the body and provide shrouds for lower-income families (I-115L). As a longer-term solution, Sheikh Jihad set up an 
informal economic cooperative and engaged in fundraising with members of the diaspora (I-115L).

Sheik Jihad located piece of land for sale in the camp for roughly US $\$ 15,000-$ 20,000 and estimated the annual cost of running and maintaining the facility at around US $\$ 2,000$. He began an informal fundraising campaign by placing WhatsApp video and phone calls to village members from Nahr al-Bared living in the diaspora, using the power of the patrilineal ahl and hamula networks to encourage contributions. For example, as a member of Samoie village, he appealed to other Samoie members living in America, Canada, and Europe to contribute money (I-116L). Boosted by contributions from other villages and families in the diaspora, the campaign soon raised enough to cover the purchase of the property and several years' worth of operating costs. Sadly, Sheikh Jihad passed away in the spring of 2018 and never saw his dream realized.

His death sparked a flurry of Samoie Facebook posts that inspired further remittance flows. On May 12, 2018, six Facebook posts eulogized his passing; the next day, three posts engaged the community in reflection on Sheikh Jihad's humility and his service to the village and camp; and on May 14 and 15, three posts reminded the community of their duty to honor Sheikh Jihad. These posts were created by different Samoie villagers living around the globe. On May 20, another post remarked that the Sheikh was gone but would never be forgotten. The funds raised following Sheikh Jihad's death were sufficient to establish a shroud collective through which the community purchases shrouds and makes them freely available to any family that needs one, so that all families can afford a basic funeral for a loved one.

My intention in interviewing diaspora members involved in this online initiative was to understand how often individuals engaged in online activity, the content of their digital conversations with their camp "cousins," and what, if any, real-world actions this engagement inspired. A member of the diaspora living in Houston, Texas, described his frequent visits to his Facebook village page and his contribution to the fund for burial facilities: "I contributed to the cost of the washroom because it gives dignity to my family. One day my mother or father or brother will pass away, and this space will be available for them and for anyone else in the Nahr al-Bared community. We cannot turn our backs on our people, especially when it comes to offering them a proper burial. We must honor our family and village still left in the camp. It is our community's way. This is the moral thing to do" (I-126L).

Another member of the Samoie village diaspora living in Boston, Massachusetts, noted:

I am a fortunate one. I got out of the camp and I have a good life for myself in the United States. My cousins are struggling in Nahr al-Bared to make ends meet. My cousin, just my same age, suffered a miscarriage and a stillbirth. Had she lived in the West with better access to medical care like me, maybe her children would have 
lived. Both times I felt the family and village must embrace her and pay for their burial, even if we are far away physically. We must care for ourselves because no one else will help us. I paid for the washroom, in part, to keep women like my cousin supported, but also I feel more deeply to be a Palestinian woman connected to my roots ... even though I live far away in Boston. (I-129L)

Palestinian refugees in the diaspora actively engaged with the community online and felt empathetic identification with people living in the camps. They were motivated to support those in the camps because they could imagine themselves in the same position, struggling to care for a loved one who had recently passed away.

\section{PATTERNS OF GIFT EXCHANGE AMONG THE POOR: LESSONS FROM THE FLATS}

Palestinian patterns of reciprocity are reflective of gift-exchange patterns among other poor and marginalized communities. The poor, whether in industrial or nonindustrial economies, lack the ability to control their environment or to acquire a surplus of scarce goods (Stack 1974; Dalton 1961; Harris 1971; Lee 1969a; Sahlins 1965). Among the Black community studied by Carol Stack, goods in limited supply were perpetually redistributed through the community. She found that the "swapping" or exchange of resources among people living in the Flats created special bonds that initiated a social relationship and tacitly agreed-upon reciprocal obligations. Often times a member of the community would ask for a small item such as a piece of clothing or food to "test" whether another person would enter into the web of connections and obligations. Some members regularly offered goods and services to other people in the community, ranging from small items of clothing or food to more costly items or services like the use of a car or child care. Some of those involved in the exchanges were biological family; others became "like family" because of the exchange.

The exchange of goods among people in the Flats was not purely an "economic commodity transfer" but an instrument for what Claude Lévi-Strauss called "realities of another order" $(1969,54)$, like status, power, and connections within the community. Similarly, for Palestinians, the transfer of remittances is not just about giving money to someone in need but serves as a vehicle for affirming the giver's relationship to the recipients. It establishes the giver's identity as a Palestinian in the world at large as a Palestinian; it cements their role and status within the ahl and hamula framework regardless of whether they are blood kin; and it generates the potential for the community to reciprocate the gift by engaging with and supporting the giver in matters of everyday life, ranging from finding a marriage partner to conducting business in the camp. As my Boston interviewee observed, giving to the camp community made her feel she was "a Palestinian woman connected to my roots." Stack observes that the "folk model of reciprocity 
is characterized by recognized and urgent reciprocal dependencies and mutual needs" (1974, 43). This cooperative communal strategy is a "profoundly creative adaptation to poverty" for both Black and Palestinian refugee communities.

A member of Safad village who lives in Nahr al-Bared echoed the importance of transnational family and village connections in supporting a family during the burial process. In 2012, the refugee's father died of a stroke. He was born in Palestine in 1935 and migrated to Lebanon in 1948. After his death, the family moved to bury the body as quickly as possible, though they waited for family to arrive from Beirut, about two hours away. They buried him in the camp cemetery near his relatives. The refugee said: "Community members and the family from Safad village supported us emotionally. We were living in the temporary metallic shipping container homes [baraksat] waiting for our home to be rebuilt after the 2007 war. Our financial status was very bad, and we noticed that our neighbors from the baraksat and our extended village abroad played a key role in helping us pay for the funeral and offering us condolences" (I-105L).

Economic remittances help cover the cost of burial but also remind families inside the camp that members of the diaspora care for them still. The reciprocal exchanges between Palestinian diaspora and their kin in the camps offer a stability that is often lacking in the turbulent, unpredictable, and poverty-stricken conditions of refugee camps. Stack found that reciprocal kin-network exchanges in the Flats engendered a similar feeling of stability: "The collective expectations and obligations of poverty stricken kinsmen in the Flats result in a stability within the kin group, and the success of these networks depends upon this stability" $(1974,24)$.

One member of the diaspora underscored the financial and emotional stability that reciprocal exchanges offer the givers and recipients:

My father was born in Palestine in 1939 and migrated to Lebanon in 1948. He died of lung cancer in 2006 . He had worked his whole life in a meat factory to support our large family of three sons and four daughters. We faced many challenges in burying my dad. One problem was finding space to physically inter the body. We decided to bury him with the family, to save space and to keep him close to our hamula. He is buried on top of his uncle. We also had challenges affording the cost of the burial. But our family and our village from all over the world contributed to it. They care about us, and so we can handle life and death challenges. (I-102L)

A Samoie member living in Virginia further explained how mutual sacrifice and reciprocal exchanges maintained community stability and survival:

I get online most days and check-in with my family and village in the camps. I use our FB page. I am strongly inclined to support my family and village with money and resources. I am the eldest son of the patriarch of our family. I am highly educated and made it to the US because of my father's and village's sacrifices. I am one of the lucky ones who got out and really made a success of himself in America. It may 
sound like a humblebrag, but I live in a huge home in a well-regarded ZIP code, and I have an obligation to help those who stayed behind and could not get out. It is the right thing to do to honor my family and community there. They are my people and my family despite thirty-nine years apart. I strongly believe that the "haves" should help the "have nots." (I-114L)

The power of traditional social networks broadcast online is evidenced by their ability to inspire second- and third-generation members of the diaspora to send remittances, even if they have never lived in the camps and had to share their meager resources. This sentiment of self-sacrifice and the richness of reciprocity among communities living in poverty is beautifully expressed in Maya Angelou's I Know Why the Caged Bird Sings: "Although there was always generosity in the Negro neighborhood, it was indulged on pain and sacrifice. Whatever was given by Black people to other Blacks was most probably needed as desperately by the donor as by the receiver. A fact which made the giving or receiving a rich exchange" (Angelou 1969, 48). A woman from the Northeast United States who was studying for an advanced degree echoed this sentiment: "If I had the means, I would give a lot of money. My cousins in Zarqa [a refugee camp in Jordan] and Nahr al-Bared have always shown me kindness. I feel connected to them even though I have always lived in America. I know finding a job is difficult for many in the camps right now, so many people are in need of financial assistance. I have given about $\$ 20$ to $\$ 40$ a month, which is about all I can afford on my graduate student stipend. Sometimes I go without to make life better for others" (I-129L). Sending remittances despite her meager resources helped the community and affirmed her Palestinian connections.

Another third-generation Palestinian, who never lived in the camps and is currently settled in Canada, affirms this insight:

I do feel like I want and need to support my family and village financially. I give them what I can. Most Palestinians I know feel the same way. Those living in Palestine, the camps, and those living overseas are all at a great disadvantage as occupied and uprooted people; from a development perspective, this has significantly and negatively impacted their prosperity and caused them much "de-development," throwing many of them into a vicious cycle of perpetual poverty. I send money to help my people out. We take care of our own, that is who we are and who I am. (I-131L)

The replication of Palestinian village kinship connections and the frequent engagement of the diaspora in digital spaces have created a springboard for mobilizing diaspora remittances. The ready flow of remittances challenges the views of technology pessimists and development scholars who predict user apathy and remittance decay. These stories indicate that Palestinians have strategically melded pre-1948 kinship obligations and shared 'adat wa taqlid to meet the challenges of community building in catastrophe. This old strategy has been made new again with the power of ICTs. 
As I describe in chapter 2, during the Ottoman era and the British mandate period, patrilineal structures of kinship linked Palestinian villagers in real and imagined ways. These connections created the bedrock of community trust that underpinned political and economic transactions in the absence of a state or outside authority. In my early camp interviews, Palestinian refugees emphasized how these codes of behavior still anchor the norms governing interactions in the camps. Speaking of how the community could easily care for itself, the owner of a glass business in the Baqaa refugee camp explained, "There are strong religious and community values that are very traditional here. It makes protection an easy thing for us" (I-12J). Another said, "I trust in God and my neighbors to protect my home and business" (I-47L). A carpenter in Baqaa said, "I rarely encountered problems [stealing, expropriation] with my business in the camp because we have strong Palestinian values. It is shameful to your family if you do these things. Everyone would know your reputation was ruined if you behaved that way" (I-9J).

Though refugee camp interactions lacked a judicial system to enforce obligations, community rules emphasize values of collective honor, steadfastness, collective self-reliance, loyalty, and shame. They are easy to put into practice, even in a transitional space, because they require little physical infrastructure or planning: enforcement depends only on social policing and community vigilance. There are steep reputation costs for the family of anyone who engages in bad behavior that damages the property of others. A sheikh underscored the importance of a family's reputation inside the camps: "If one's family name was tarnished, it influenced the ability of people to marry well and conduct future business in the area. A bad event had implications for future generations in your family" (I-79L). A Palestinian working for UNRWA attested to the power of these unwritten rules: "If Nahr al-Bared camp were a Lebanese village, they would have much more crime. But they don't. They don't fight that much. It is because they have strong traditional values for protection" (I-5L).

Of course, as in any community, there are conflicts and petty crimes but, for the most part, camp residents reported feeling safe in their community because strong values of honor and shame anchor their communal behavior.

These values also promote cooperation. Extensive reciprocal exchanges are found among communities living in challenging conditions. Black communities in the United States, historically and legally marginalized and isolated from state structures, devised a social system in which strategic resources are distributed from a family base to a domestic group, and the reciprocal exchanges pervade the whole socioeconomic life of the community (Stack 1974, 38).

Still, a cynic might suggest that my interview evidence provides, at best, anecdotal support of the idea that those "angels" among us are always likely to help or give to others in need, and that they are the same people who are likely to log on to communal Facebook pages. The interviews highlighted above emphasize the effectiveness of communal values in shaping interactions only inside the camps; 
they do not address the issue of how these values influence behavior among members of the diaspora.

In chapter 1 I outline the central causal argument for reciprocity in digital spaces, based on the experimental work of Ernst Fehr and colleagues. They suggest that enforcement is dependent on the presence of a party with enough power or will to reward compliance and punish defection (Fehr, Fischbacher, and Gächter 2002; Fehr and Rockenbach 2003). Even in situations where selfishness would be very easy, because of fewer encounters and less observable action, reciprocity may occur if there is an "enforcer." Specifically, Fehr, Fischbacher, and Gächter (2002) consider how cooperative relationships arise even in contexts in which pure self-interest would cause a breakdown in reciprocity. A strong reciprocator, or an individual with a "pre-disposition to reward others for cooperative, norm-abiding behavior, and a propensity to impose sanctions on others for norm violations" can effectively motivate reciprocity and mobilize resources (Fehr and Rockenbach 2003).

Stack's ethnographic study of Black kinship and reciprocity in the Flats community underscores the importance of repeated, informal interactions in highcontext spaces. One of her respondents, Ruby Banks, asserts that someone who does not reciprocate will face communal sanctions: "Everything that goes around comes around in my book" (Stack 1974, 41). In other words, reciprocity is likely when there an individual, or an entire community, acting as an enforcer of culturally specific ideas of right or wrong behavior.

\section{THE AMISH EXAMPLE: SEPARATENESS, SHARED VALUES, FUNDING THE COLLECTIVE GOOD, AND SHUNNING}

The example of the Amish community in Lancaster County, Pennsylvania, intentionally living separate from state structures and enforcing their own behavioral norms, provides a powerful comparative case for understanding digital interactions and reciprocal exchanges in contemporary refugee conditions. Amish communal life, structured around the church and a tacitly understood Ordnung, or way of life, provides examples of easily replicable social norms, including the use of Meidung, or shunning, to mobilize resources and maintain community cohesion.

The Amish faith emerged in Switzerland in 1693. The Amish split from the Anabaptist community as the result of a disagreement over the use and practice of shunning. Anabaptists excluded wayward members of the community from holy communion but did not ostracize them socially. The Amish faith's founder, Jakob Amman, felt that expelled or shunned members should not only be banned from communion but also shunned in daily life (Kraybill and Bowman 2002).

The enforcement of shared values is important because the Amish community purposely separates itself from the outside, "modern" world, eschewing many modern technologies, and emphasizes community self-reliance. In order "to stay 
whole, or to preserve their snug community," the Amish have crafted a distinctive set of structures, traditions, networks, and rituals that "have been invested in the social bank, so to speak, and can be mobilized to serve the entire well-being of the community and individuals as well" (Kraybill and Bowman 2002, 20). Communal life is organized around three basic social units: the settlement, the district, and the affiliation. Unlike the Palestinian ahl and hamula units of organization, these units are explicitly associated with religious faith.

The settlement is a common geographic area that encompasses anywhere from dozens to thousands of Amish people. A district is a congregation or church organizational unit made up of twenty-five to thirty-five families. The affiliation is a cluster of congregations or districts that are in spiritual fellowship (Kraybill and Bowman 2002, 13-14). These social units share a base of knowledge and accepted values, norms, beliefs, and obligations that "help motivate and inspire individuals to act on behalf of their fellow members and community" (Kraybill and Bowman 2002, 20).

Amish norms of behavior are embodied in the Ordnung. According to one Amish man, "The order is not written down. The people just know it, that's all." Through actions and stories, this way of living becomes ingrained, such that it is "taken for granted as reality in a child's mind" (Kraybill and Bowman 2002, 112). For example, when a child is born in an Amish home, several adult women come to assist the new mother and care for the baby for a while. Within two or three days of a barn fire, the community erects a new barn. "This gigantic task happens ritualistically, seemingly almost without effort" or formal structures to organize and pay for the barn. Behavioral norms stipulating that one should "yield to the needs of the community above one's own generate an abundant supply of capital that serves the common good" (Kraybill and Bowman 2002, 21). This happens spontaneously because it is a habit of communal orientation and woven into the texture of daily life (Kraybill and Bowman 2002, 143).

Though the overwhelming majority of Amish uphold the Ordnung, there are still "wayward" members who challenge community values, usually by adopting technologies that put their own interest ahead of the community's and eschewing "nearness" (Kraybill and Bowman 2002). In cases where ritual confession or gentle nudges are insufficient to guide an individual toward choosing a better path that is in line with Gelassenheit, or submission to God's will, the community resorts to Meidung, or shunning. The ban from religious and daily communal life "is the ultimate form of social control" and the "teeth" of Amish discipline (Kraybill and Bowman 2002, 21). Shunning or shame is an exceptionally powerful tool for social control in the absence of formal state structures. One Amish person facing Meidung described what it felt like. "You suddenly lose all your security, and you become a goat, like a piece of dirt" (Kraybill and Bowman 2002, 114) It is the cornerstone of Amish reciprocity because it gives credibility to the system and helps ensure resource mobilization. 
THE POWER OF SHAME IN DIGITAL SPACES

Kraybill and Bowman's study of Amish life explicitly rejects the notion that a similar sense of spontaneous communal caring, providing a collective pool of resources and supporting the well-being of the community and its members, can arise in cyberspace. They authors consider cyberspace to be "context free," whereas Amish people interact with others in a "high context" culture. They know more than just another person's avatar, name, or email address: they know their parents and grandparents, their church district, ministers, their occupation and hobbies, and their status in the community, as well as their temperament. They operate within a deeply embedded, highly contextualized set of relationships that are "quite different from the multitude of transitory ties in modern society and cyber space" (Kraybill and Bowman 2002, 150-51). Yet Palestinians effectively elicit reciprocity online, in the form of remittance flows, precisely because they have created a high-context digital space with easily replicable norms of loyalty and collectivism, rooted in the ahl and hamula and strategically enforced by means of ayb. Just as an Amish person knows the Ordnung because it has been ingrained in their daily life, Palestinians know the value of honor, loyalty, steadfastness, shame, and collectivism in digital spaces because these principles are constantly replayed in digital life and reinforced at home.

Extending the power of shame to digital spaces is a tricky endeavor because, in the view of scholars like Kraybill, the digital space provides anonymity and a sort of disembodied "utopia" where one's real-world positionality does not matter. Much of the early technology-optimist literature suggested that the internet would be a liberatory space, especially for women and communities in repressive Arab states. For example, writing in 2005, Fereshteh Nouraie-Simone saw cyberspace as a virtual "room of one's own" in which women would be able to transcend repressed social identities (61-62). Musa Shteiwi wrote that the internet's focus on the individual rendered "traditional social control mechanisms of [women's] behavior useless" $(2003,489)$, and Masserat Amir-Ebrahimi compares blogging to a "virtual unveiling" (2008, 90).

However, cyberspace cannot be seen as what Jesse Daniels (2009) terms "a liberation utopia of disembodiment" $(102,110)$. Real-world hierarchies are not suspended online, and experience has proved that the internet is not a safe space for marginalized people. ${ }^{1}$ Of course, a person's identity is never fully secret in digital spaces, but the illusion of anonymity may generate some very bad behavior. Online interactions exhibit a lot of the negative aspects of transitory encounters, like cyberbullying and "throwing shade" with remarks that people would be less likely to utter in public life.

Kraybill and Bowman (2002) note that the Amish strategically engage with technologies in ways that cultivate nearness and community cohesion. In much the same way, Palestinians interact with ICTs in a way that cultivates nearness and 
community in their perpetual state of dispossession. Because these digital spaces are patterned on pre-1948 ahl and hamula identities, users know other people's full social context dating back to pre-Nakba times, including family lineage and reputation. There is no anonymity on an ahl-hamula Facebook page.

A young Palestinian woman who has grown up in the United States and lives in Portland, Oregon, eloquently shares how it feels to interact with Samoie villagers online and in real life:

Though I live in America and grew up here, I live in a world within a world. I am a nineteen-year-old American college student on the surface, but that is just what others see. I am actually a daughter of a family that comes from Samoie village, and my entire understanding of my identity, what I stand for, and who I am connected to and associate with today is rooted in a village I have never been to except for through my father and mother's memories. The Palestinian village and all the associated gossip and the business-like who is marrying who, and who has a new job, and who has money or doesn't-of village life persists today for me. Whether I am online engaging in social justice activism or whether I am visiting my parents and having dinner, I am fully aware of expectations of who I am, what I stand for, and what everyone else that matters in this world expects of me. There is no escaping that, despite the physical distance from Palestine and much of my kin. (I-130L)

One Samoie villager who grew up in a camp in Lebanon but now lives in Houston, Texas, said:

Even on the Facebook group page, we share the collective trauma of the Nakba and the continued dispossession of our people from our ancestral homeland. 1948 might feel like a time long gone for many people, but for people from Samoie village like me, well, you see, we are reminded every single moment and every day of our collective suffering when we see Zionist occupiers destroying our people and land. This makes me and my children remember our connection and obligation to our community. I want to take on the suffering of the suffering people in the camps. I can never do it completely, but I want to ease the pain and make their life a little better by giving money to pay for their medical fees, education, or food. We have a shared special tie with our relatives even in a digital space. There is an obligation to support them because of our community ties and shared trauma. (I-120L)

One man who grew up in the camps but has children who have only ever known life in America observed:

My children have never experienced the suffering of being hungry and feeling poor. When they were young children, I would take them on trips to Nahr al-Bared and Rashidieh camps, where we have family. I would take them to the poorest relatives, not to make them feel superior or like wealthy people are better than the poor. I was trying to show them humility, compassion, and empathy for those that are our blood connection but need help. I would give them money to dole out to family and friends in the camps. They got to experience what giving feels like as children. Now that they 
are older and married themselves, they have the habit of giving to family. When a story pops up on the Samoie [Facebook] page, they don't even question the necessity of sending money to help. It is an ingrained behavior for them. (I-127L)

A third-generation Palestinian from Samoie village living in Texas said:

Everything in our life is structured around our family and extends to the village. My parents are from neighboring pre-1948 villages and grew up in Lebanon, then came to America in the 1980s. Even in Houston, our Palestinian roots are strong. At home, Baba and Mama talk about the importance of caring for those in the [refugee] camp. And online, I see it all over Facebook on the village page too, that we are supposed to take care of each other because no one else will. Everyone on there is related to me-we are all like cousins. The main thing to know from all these interactions is: family and village come first, always. (I-126L)

These comments show that digital relationships on line are full bodied, high context, and lifelong. A high-context digital space enables strong reciprocators to enforce communal norms just as they did in face-to-face interactions in the villages and refugee camps. In such a digital space, 'ayb is as powerful a force as Meidung in Amish settlements.

The community obligations of sending remittances and protecting the vulnerable are reinforced by patrilineal kinship ties. These obligations are informal and unspoken because, as Amos Nadan observes, a need for signed agreements between community members "would be regarded as shame or 'ayb" $(2006,196)$. The power of shame in communities means that informal tools may suffice to enforce good behavior, punish defectors and shirkers, and ensure the continuation of remittance flows. One man said:

I was a lucky one that made it out. My entire family sacrificed so I could be the one to make it. My sisters did not get to go to school, even though they were brilliant, because we could only afford one tuition. We all nearly starved in the early years so that I could go to school. I weighed barely one hundred pounds when I started college as a seventeen-year-old. When I got my first full-time paying job as an engineer in Saudi Arabia, I sent almost 70 percent of my income back to my family. I felt it was my honor and duty-no, even more than that, it was my moral obligation to help my entire family and village by giving them money from my paycheck. It would be 'ayb, shameful, to turn my back on them. Of course, I help fund whatever is needed, like the most recent shroud cooperative and burial washroom. I also send many young kids to college by paying their tuition for medical school or engineering. I make them send me report cards before I wire the money. (I-123L)

Though asking for proof of a report card may seem as though the sender does not fully trust the recipient of the money; I think this reciprocal exchange highlights what Mauss (1954) believed to be implicit in every single "gift." The gift recipient may not be able to return a gift in kind to the giver, but presenting the giver with a report card indicates an awareness of upholding one's communal obligation to 
be a good student, to show it through grades that the student proudly displays, to represent the village well in the school setting, and to one day do well enough in a career that they can maybe "pay it forward" to the next generation. When pressed to explain how shame played out in the community, a Palestinian echoed the description of Meidung experienced by Kraybill's Amish interlocutor.

My entire being is wrapped into this community. If I acted poorly, like not sending money ... oh, I would hear about it, even though I lived in America and didn't plan to return to the camp. Let me tell you a real example. I mean, the fact that I am sharing this with you shows how far the rumor and bad talk about this person has pervaded the community. There is a respected man in the camp, he has a successful business. He traveled abroad during the early 1970s and made lots of money. All of this is great, right? Well, the shame in the whole story is that he is so filthy rich, owns a bunch of companies, and lives in Amman, Jordan, now but doesn't give back to the village in the camp at all. I hear he has fancy cars and wears designer-label clothing. He has been divorced a couple of times and he ended up marrying a Jordanian woman because no Palestinian family or woman would take him, because he also has never sent a single penny back to the camps. Can you imagine wearing a designer suit while your family in a refugee camp suffers? It is so disgusting. Even his own brother and sons are embarrassed and ashamed of him. They deny their connection to him and talk bad about him. He is a dirty stain on the family name. They must deny the connection, or no one would ever do business or marry into their family, because he is not a person that takes care of his people. He denies his family and roots and crossed a line no one should cross. (I-120L)

On the basis of the rumors about this man's behavior, the community shuns him and anyone who willingly associates with him. Shirking community responsibilities carries financial costs as well as reputational costs because of others' reluctance to do business or marry into a family with a perceived shirker or defector.

A recent online marriage match highlighted the importance of reputation for a hopeful groom. A Palestinian woman connected with a Palestinian American man through their village's Facebook page. Brief written exchanges online led to a series of WhatsApp calls and eventually a FaceTime meeting. When he mentioned marriage, the woman expressed interest but noted that her brothers would have to research his behavior and reputation before permitting the marriage. I asked the brothers about how they did this. One told me:

I want my sister to marry a man who takes carry of his family first, and the best way to know if this is going to be true is to ask his family in the camps if he sends money to them or gives them gifts. If he is a selfish American guy, he would just keep the money to himself and deny his family left in the camps. My sister deserves a man who will respect his family and our traditions. I learned that the guy, who we are distantly related to, does send money to his sisters and regularly helps out. I talked to his entire extended family to confirm the truth. He has not visited the camps in a long time, but he sends money. His honorable behavior meant we would support their engagement and marital contract. (I-128L) 


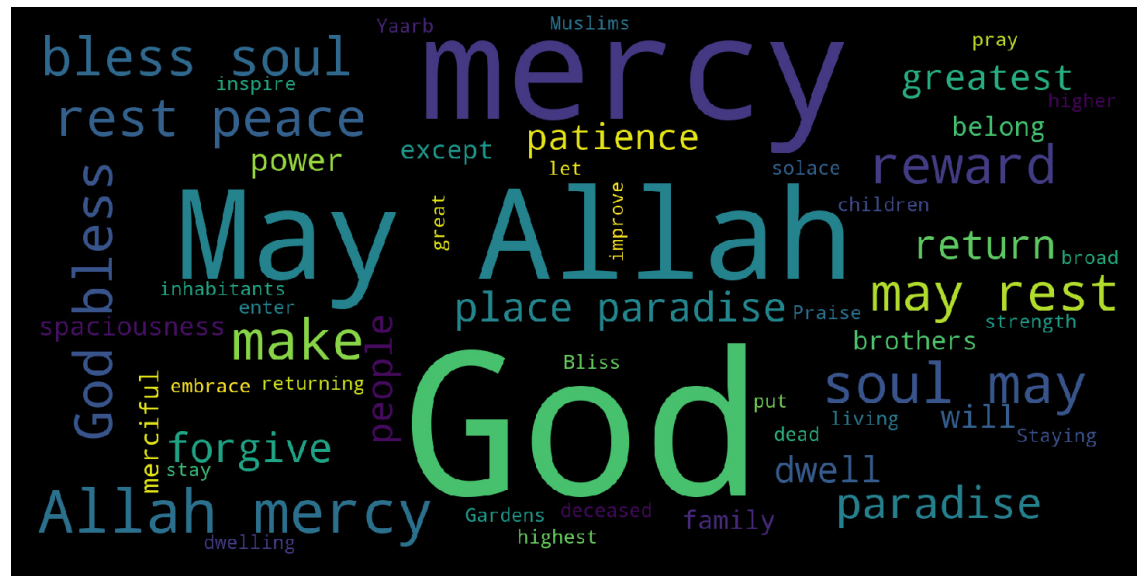

FIGURE 6. Word cloud of the most common words appearing on Samoie village Facebook page, May 2017-May 2018.

Though the man had lived in America for more than twenty years, his reputation for regularly sending remittances back to the camps made him a suitable partner for a woman from a respected family. I asked another of the woman's brothers what would have happened if they had learned that the hopeful groom was not a reciprocator. "Well, there would be no more talking between the two of them online," he responded. "It would mean maa'-salaami, or goodbye!" In sum, not contributing to the community incurs practical material costs that serve as a powerful incentive for reciprocity.

Yet another interviewee said, "It is because we have strong traditional values for community self- protection that we can get remittances today from our family and village living abroad" (I-115L).

A culture of shaming was evident in frequent passive-aggressive digital posts that criticized members of the diaspora community when they were not sufficiently responsive to calls for sending money or supporting the camp. A large number of posts on the Samoie Facebook page are religious in nature. Initially, it seemed that this indicated the deep religiosity of the community. Examination of a "word cloud" highlighting the top words on the Facebook page emphasized mercy, God, Allah, blessing, charity, virtues, and a variety of Islamic religious terms (see figure 6). However, interviews revealed that these religious posts often had a subtext. One particular user from Nahr al-Bared (referred to below as X) often posted images of the community cemetery littered with trash. He also shared images of old people sitting abandoned in wheelchairs in the camp and cracked or broken tombstones. He sometimes typed below the pictures, "Who among us cares for our community?" and added a separate post of a Qur'anic verse about the duty of the wealthy to serve the poor, such as "And as for those who strive in Our path-We 
will surely guide them in Our ways. And Indeed, Allah is with those who are of service to others" (29:70). Another post quoted the verse "Indeed, Allah is with those who are righteous and those who do good" (16:129).

His shaming posts struck a nerve among a digital community well versed in expectations of loyalty and collectivism. A deeply religious member of the Samoie diaspora in North America responded by linking his giving to his family and religious upbringing: "It is my shared connection and obligation to my village to send money to help those in the camps. Beyond my familial ties, my Muslim faith makes it incumbent for me to give zakat, or tithing. This is one of the five basic pillars of Islam, to give to those in need. So of course for me, there is no question that a percentage of my income must go to those in the camps that need help" (I-12oL).

In the high-context space of the village Facebook page, these posts had powerful implications for the diaspora audience. One said:

Oh man, every time $\mathrm{X}$ posts his religious verses and these horrible pictures of my family's broken gravestones or old people languishing in wheelchairs in a crappy alley, I feel so guilty and ashamed. Sometimes it is like he is directly aiming the posts at me. He will post a picture that includes an image of my grandfather's grave. I really know it is directed at me. Sometimes I felt like he knew what I was doing on the other side of the screen [chuckling, laughing], because I would be shopping online at Amazon for some random thing I didn't need and then quickly empty my digital cart and wire one or two hundred bucks via Western Union or send some money in the suitcase of a relative heading to the Middle East to give to people in the camp. I have to give money to feel okay about myself and my family. I haven't ever lived in the camps, but I know what I am supposed to do. You get treated like shit if you do not give when the community needs it. It is a good reminder to not be a selfish jerk. I know they are right too, in my heart. (I-128L)

Another second-generation Samoie villager, who grew up internationally, described how conversations with her father, who grew up in Palestine and the camp, shamed her into giving money.

My Baba doesn't use Facebook, but every now and then I would bring up something I saw on the Samoie page. When the young kid got burned at the end of last month [May 2019], I felt so awful. I called up Baba and asked him, "Are we related to that boy?" He affirmed the connection. He told a story from Palestine of how he was playmates with the grandfather of the child. He said that they really needed the money and how it would make such a difference to their family and our village. He also emphasized how much it would mean to him if he could say I gave money too. He would feel very proud to say his daughter cared for those in the camp. He added, "You have so much, what is a few hundred dollars to you? Nothing. It is shameful to not give something that would mean so much to them and costs so little of you." So I felt a lot of pressure to do the right thing, and I didn't want to make my Baba feel ashamed of me. It is really weird, you know? I mean, it is odd how the Facebook page and my Baba's words interact to make me give money. It is the right thing to do, even if there is a selfish part of me that wouldn't give without some of that pressure. (I-124L) 


\section{THE DARK SIDE OF SHAMING}

Though interviews and surveys from Samoie villagers evidence that shame is an effective tool for enforcing reciprocity in digital spaces, it also has a dark side. Any person who identifies with or behaves in a way that deviates from the patriarchal village structure and behavioral norms may be ostracized, or worse. Women who divorce or choose nontraditional career pathways and queer communities suffer from the rigid understandings of honor, loyalty, collectivism, and steadfastness in the Palestinian community. Rather than bringing people together, shame may be used to tear apart individuals and their families and villages. Furthermore, this alienation may erase the patterns and obligations of reciprocal exchanges necessary for community survival.

Brené Brown discusses shame as a "silent epidemic: associated with depression, grief, anxiety, eating disorders, addiction, and violence." She defines shame as the intensely painful feeling or experience of believing we are flawed and therefore unworthy of acceptance and belonging. Women and nonheteronormative individuals often experience shame when they are entangled in a web of layered, conflicting, and competing community expectations. Brown finds that shame "creates feelings of fear, blame, and disconnect" $(2007,29)$. Even women who do not follow the established and expected life pathways of marriage and children face isolation and pressure to conform or risk being sidelined in family and community interactions.

Louise Cainkar's research on Palestinian women in Chicago demonstrates the downsides of patriarchal norms for community members, even those living far away from the camps, who choose nonendogamous marriage partners, divorce, or follow nontraditional career paths. She found that Palestinian women's attachment to families and patriarchal practice allowed families to continue exercising traditional patriarchal notions about women even after immigration to Chicago. In particular, "In a community like the Palestinian, where maintaining traditional culture is politically extremely important due to statelessness, occupation, and diaspora and because this work of course must primarily be done in the home or in the confines of the community, women are under more pressure than men to be traditional and maintain traditional roles. Consequently, gender and politics interact to place a double burden of tradition keeping on Palestinian women" (Cainkar 1994, 88).

This "double burden" was especially visible in marital matches. Marriage of a Palestinian Muslim woman to a non-Arab, especially a non-Muslim, was deeply frowned upon by the entire Palestinian community, regardless of social class. These attitudes remain prevalent today. Of the fifty young men and women I surveyed between the ages of 18 and 30 living in the camps and in the diaspora, 80 percent felt that the "old ways" of being a Palestinian in the world persisted despite the influx of new ideas and experiences in the West. Most of the young people I 
interviewed who married during the six-year survey period stayed within their kinship framework. The remaining 20 percent represent a significant departure from traditional norms.

Though Palestinian political elites often adopt a rigid attitude toward different identities and groups, local ahl and hamula interactions, especially among digitally connected youth, suggest that Palestinian notions of what is honorable and shameful are potentially quite malleable. One young survey respondent wrote:

Palestinians raised in the West are inevitability going to have a different twist on many issues, though young people in the camps feel pretty similar to me the more we interact online. For example, we are used to the idea of dating and premarital relations-there is a difference in finding marriage for us than how our parents and grandparents did it. It shifts away from how we normally do things as Palestinians. We are more focused on love matches than on bridging family relationships through intrafamily marriages. Finding love for ourselves is most important, not family honor. I don't know, maybe finding love is a part of honor too. (S-49)

Another young woman wrote in her survey response:

I am currently working on a $\mathrm{PhD}$ in science, have no plans to get married ever, and am an open atheist. Many of these ideas go against core values in my Palestinian family and village. My Palestinian uncles/aunts and I have argued about the importance of education for women and the role of women in the home in the past. My Palestinian relatives in the U.S. know that I am living with my partner and that we are not engaged. These ideas are different because many of my aunts and uncles do not believe education is as important for their daughters as it is for their sons and have actively barred their daughters from going to college or school. My extended family also stresses the importance of marriage and having children for women in their 20's constantly, whereas I encourage my cousins to wait for those things until they are older. (S-26)

In her oral response to the survey, she continued: "I think my ideas about female education are catching on in the extended Palestinian community-heck, my cousin just became the first female medical doctor from our family in the campbut I don't think my ideas about marriage are going to catch on any time soon, as never getting married but having a loving partner is a pretty radical viewpoint, even for people my age in the US" (S-26).

Women who deviate from prescribed social norms are socially ostracized. One of my survey respondents shared the social loneliness and humiliation she faced during her divorce from an American man and the unexpected ways in which real-world and digital shame collided.

When I went through my divorce in America, my uncles in the camp were terribly ashamed that I would speak about it publicly and that I posted my status change from "married" to "single" on my Facebook page. The family patriarch, my uncle, called me from Nahr al-Bared and told me I would go to hell for abandoning my marital 
vows. I explained to my uncle that my ex-husband had cheated on me and showed no remorse. He left me. My uncle did not care. He also smugly said, "That is what you get for marrying an American guy for 'love' and not a Palestinian man from the village for family honor." So that was how the old guard spoke about divorce. I was terribly distraught. But in other conversations with young people from the village online, the talk and feeling was different. I am very close to my second cousin, A. We were playmates when I went to the Middle East in the summers as a child. During my divorce, he and I chatted daily online and occasionally on WhatsApp calls. Anyways, A married a non-Palestinian woman he met in college for love, so we often talked about marrying for love and not for the family's traditions. He was proud of me for holding my head high during the divorce and he said he would never have stuck around if he had been in my shoes. The younger generation doesn't think of divorce like our parents do. We think there is more to life than just keeping up some image of a perfect marriage for the purpose of preserving the family's honor in the community. Our personal welfare sometimes is more important than the family's reputation. (I-111L)

In her account, village elders reinforced rigid codes of honor and isolated her with shame. However, in an online conversation, a cousin conveyed to her a new message of Palestinian respectability, dignity, honor, and steadfastness: in the face of a Western man's betrayal of vows, she was a strong Palestinian woman who held her head high and pushed on. As Walaa Alqaisiya astutely asserts in her study of queer Palestinians, "On the one hand, performativity explains how social norms emerge from a repetition and reiteration of certain acts, which (re)produce dominant power structures. On the other hand, it identifies how potentialities and possibilities for re-signification of those dominant norms lie within their performative repetition $(2018,38)$."

In effect, honor and steadfastness can be performed in different ways by Palestinians, and digital spaces give room for this subversion of shame. As Judith Butler suggests, "Possibilities of gender transformation are to be found precisely in the arbitrary relation between such acts, in the possibility of a failure to repeat in 'proper' terms the gendered identity ascribed to us $(1999,179)$."

The cost of shame is also evident members of the Palestinian community who identify as queer. Queer communities are often slurred by being erroneously cast as collaborators with Israel and dishonorable to the Palestinian cause. Alliances among Israeli and Palestinian queer communities are widely viewed with suspicion. Political organizations like the PLO and Hamas explicitly reject the LQBTQA+ community and engage in targeted homophobic harassment (Alqaisiya 2018; Ashtan 2020; Schotten 2018). However, engaging with Palestinian homophobia is tricky because, as Heike Schotten (2018) observes, criticism of Palestinian political elites and their institutions, and society more generally, often invites policy elites, humanitarian groups, and Western activists to proclaim the orientalist adage that "the natives don't know what is good for them" and to represent Israel's "democracy" as exemplary in its embrace of the queer community. 
Palestinians, and queer Palestinians specifically, challenge orientalist worldviews because they do not disappear "as they ought to" (Said 1978). Schotten maintains that queer Palestinians "constitute a form of dissidence by their very existence" and observes that Said's characterization of Palestinians as troublesome resonates with queer theory's "defiant attachment to all those who are not or cannot be made assimilable. Indeed, the inassimilable is in some sense who and what queer names-that illimitable list of deviant others whose existence destabilizes, disrupts, or thwarts the otherwise smooth functioning of institutionalized, hegemonic regimes of normalizing, heteronormative power" (2018, 15-16).

Palestinian queer communities, embodied by groups like alQaws (whose name is an abbreviation of "rainbow" in Arabic), challenge the norms of both colonialist state-building projects and nationalist ideas rooted in patriarchy (Alqaisiya 2018, 38). Interestingly, alQaws has strategically avoided collusion with Israeli pride groups without affirming restrictive Palestinian patriarchal notions of honor and shame. For example, Palestinian Queers for Boycott, Divestment, and Sanctions (PQBDS) played a pivotal role in the campaign for economic protests against Israeli settlements and reoriented local civil society's understanding of the queer Palestinian subject as an honorable resister of Israel's occupation and a champion of Palestine through much of its digital activism(Ashtan 2020).

It is easy to see how shame has been used to ostracize and alienate these communities and undermine connectedness among all kinds of Palestinians such that reciprocity is eroded. I do not intend to offer an overly optimistic vision of the full embrace of the queer community by transnational Palestinian villagers; but I think we may underestimate the compassion and transformative resilience of the ahl and hamula networks.

In his poignant introduction to Queer Palestine and the Empire of Critique, Sa'ed Ashtan shares the story of coming out to his ahl in the Occupied Territories. When he came out to a close Palestinian Christian friend, he was shamed and rejected. But when he came out to his mother, she embraced him and said, "The reason that I am crying is that I cannot believe you have gone through all of this without me. I wish that I had been able to be by your side. But I am now comforted that you have come to me... This is something incredibly difficult in our society, but you are my son. I love you, forever and always" (Ashtan 2020, introduction).

Ashtan also recounts how his cousin introduced him to another man, a potential romantic partner, without comment about his sexuality, as if it were normal in Palestinian society. He finds it amusing that his Palestinian family still wanted to play an active role in matchmaking, even in queer romantic relationships. Although anecdotal, these stories indicate the hope and potential for a more expansive and inclusive set of Palestinian norms and a revised understanding of what constitutes shameful behavior in families and villages. As I suggest in chapter 4, digital spaces offer an opportunity for the Palestinian community to remake its understanding of itself, its political vision, and how it operates in the world. 


\section{CONCLUSION}

The strategy of turning toward the pre-1948 village and family unit to connect with the diaspora network in digital spaces has encouraged members of the diaspora to send remittances to partially solve the protection-gap dilemma for refugees in the camps. This strategy is reinforced and strengthened by village and family ties. The ability to mobilize digital connections to raise funds for facilities like the communal burial washroom and shroud collective is astounding given the protracted nature of the Palestinian refugee conflict and the geographic distance separating Palestinians living in the camps from those in the diaspora.

Nahr al-Bared's respected religious elder, Sheikh Jihad, was careful to note in interviews that though certain families or villages might have donated more than others to the fund for burial facilities, his intention was to make the resources accessible to all the families and villages in the camp, regardless of place of origin, income, or status (I-116L). He emphasized, "We take care of all our people, even in death" (I-115L).

Collective undertakings like this mirror Prerna Singh's insights on the role of group identity in fostering collective welfare (2015a, 506). In her study of Indian subnational identity, she finds that attachment to a subnational rather than a national identity encourages positive actions, like redistributing collective goods. She contends that subnational group identity, commonly thought of as exclusionary, insular, "tribal," and chauvinistic, might be reframed as a shared identity that could produce better lived experiences for the entire community.

Contrary to the views of technology pessimists, representation of the ahl and hamula in Palestinian digital spaces, along with easily replicable and enforceable norms of honor, loyalty, and shame has generated extensive remittance flows from the diaspora. The financing of collective welfare projects signals both the nearness and capacity of the community. Encouraging remittance flows depends to some measure on the power of ayb, or shame. Although this can be damaging to individuals who identify or act in nontraditional ways, there is some evidence that notions of shame are malleable. 